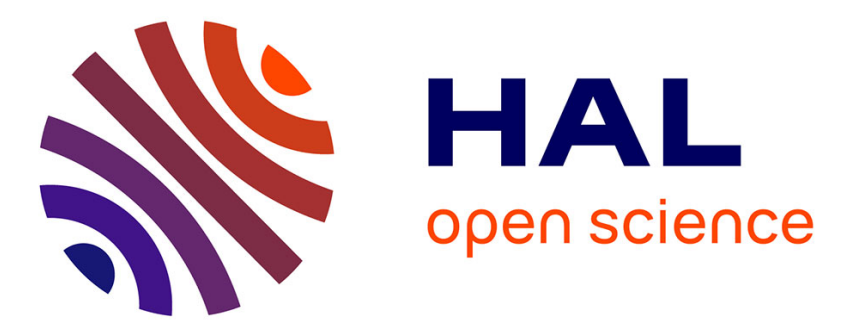

\title{
Flower visits, nesting and nest defence behaviour of stingless bees (Apidae: Meliponini): suitability of the bee species for meliponiculture in the Argentinean Chaco region
}

Favio Vossler

\section{To cite this version:}

Favio Vossler. Flower visits, nesting and nest defence behaviour of stingless bees (Apidae: Meliponini): suitability of the bee species for meliponiculture in the Argentinean Chaco region. Apidologie, 2012, 43 (2), pp.139-161. 10.1007/s13592-011-0097-6 . hal-01003637

\section{HAL Id: hal-01003637 \\ https://hal.science/hal-01003637}

Submitted on 1 Jan 2012

HAL is a multi-disciplinary open access archive for the deposit and dissemination of scientific research documents, whether they are published or not. The documents may come from teaching and research institutions in France or abroad, or from public or private research centers.
L'archive ouverte pluridisciplinaire HAL, est destinée au dépôt et à la diffusion de documents scientifiques de niveau recherche, publiés ou non, émanant des établissements d'enseignement et de recherche français ou étrangers, des laboratoires publics ou privés. 


\title{
Flower visits, nesting and nest defence behaviour of stingless bees (Apidae: Meliponini): suitability of the bee species for meliponiculture in the Argentinean Chaco region
}

\author{
Favio Gerardo VosSLER \\ CONICET, Laboratorio de Sistemática y Biología Evolutiva (LASBE). Museo de La Plata, Paseo del Bosque s/n., \\ 1900 La Plata, Argentina
}

Received 28 March 2011 - Revised 31 August 2011 - Accepted 18 September 2011

\begin{abstract}
Four bionomical features are here described for the seven stingless bees that inhabit a new meliponine beekeeping area: the Argentinean Chaco region. The most commonly visited plants were of herbaceous habits, predominantly had flowers of white/creamy to yellowish colour, with small-sized flowers and were of moderate mass-flowering degree. Lestrimelitta chacoana was the only robber species. The most commonly found nesting substrate was large living tree trunks, and most nests were found at the base of the trunks. Sometimes, nesting substrates and floral resources were provided by the same woody plant. Cryptic small- to medium-sized cerumen tube-like unornamented nest entrances were the most commonly found. Nest defence included aggressive (Scaptotrigona jujuyensis) and docile behaviour; the latter was classified into timid and non-timid. A key to identify the Meliponini fauna of this region is provided. The regional pattern of bionomical features seems to be associated with subtropical climate conditions. The majority of these bee species are suitable for Meliponiculture in the Chaco region.
\end{abstract}

aggressive bee / dead tree trunk / docile bee / living tree trunk / subtropical Meliponini bees

\section{INTRODUCTION}

Meliponini are the eusocial bees characteristic of the moist tropics of the world, and their richness decreases towards the temperate regions of the subtropics (Michener 1990; Alves dos Santos 1999). In the Neotropical region, stingless bee distribution extends to about $35^{\circ} \mathrm{S}$ (Michener 2007), including the Chaco forests of central South America (the Chaco region).

Corresponding author: F.G. Vossler, favossler@yahoo.com.ar Manuscript editor: Klaus Hartfelder
Around the world, stingless bees display considerable diversity in food sources, nesting substrates, nest entrance architecture and nest defence behaviour (Schwarz 1948; Wille and Michener 1973; Roubik 1982, 2006; Camargo and Roubik 1991; Camargo and Pedro 2002, 2004; Couvillon et al. 2008; Rasmussen and Camargo 2008). Like all bees excepting the parasite genera, they forage on flowers for pollen and nectar. Stingless bees are polylectic or generalists because they collect pollen from several non-related plant families (Robertson 1925; Michener 2007). Sugar sources are commonly supplied by nectar from flowers. However, hemipterophily (collection of honeydew) exists in some Trigona species, Oxy- 
trigona tataira (Smith), and Schwarzula coccidophila Camargo and Pedro (Laroca and Sakakibara 1976; Camargo and Pedro 2002). Pollen is the main protein source; however, animal protein can also be consumed. Facultative necrophagy occurs in Melipona grandis Guérin, Cephalotrigona capitata (Smith) and Trigona pallens (Fabricius), among others, and obligate necrophagy in the Trigona crassipes species group (Schwarz 1948; Roubik 1982; Camargo and Roubik 1991; Noll 1997; Rasmussen and Camargo 2008). Furthermore, Lestrimelitta and Cleptotrigona species, Melipona fuliginosa Lepeletier and possibly Trichotrigona extranea Camargo and Moure are robbers of pollen and honey stored in the nests of other stingless bee genera (Sakagami and Laroca 1953; Roubik 1983; Camargo and Pedro 2007b). Robber stingless bees are considered a threat to Meliponiculture as they attack, rob and even kill the reared colonies (Schwarz 1948; Sakagami and Laroca 1953).

Meliponini colonies are perennial and most nests are built in preexisting hollows within different substrates such as tree trunks (living and dead), ground, brick walls and active nests of termites, ants or wasps. Most aerial nests (exposed and semi-exposed) house aggressive species (Roubik 2006). Nesting substrates may be species-specific and highly diverse even within the same genus, e.g. Partamona, Trigona s.s. (Wille and Michener 1973; Roubik 1989, 2006; Camargo and Pedro 2003; Rasmussen and Camargo 2008). In the Chaco region, the forest has been degraded mainly by agriculture, logging and grazing, leaving isolated forest fragments. These practices constitute a threat to tree trunk-dependent animals such as several stingless bee species.

Nest entrance architecture is species-specific and highly diverse in stingless bees (Camargo 1970; Roubik 2006). The nest entrance features are the results of a compromise between the functional roles of defensivity and foraging traffic (Couvillon et al. 2008). This structure include a wide variety of building material (cerumen, mud, sand, resin, plant and animal particles, either mixed or pure), shape (tube- like, funnel-like, mouth-like, etc.), size and external sculpturing (presence of root-like projections in Lestrimelitta, etc.; Wille and Michener 1973; Roubik 1983, 1989, 2006; Camargo and Pedro 2003).

Nest defence behaviour from humans has been classified in different ways. Michener (1961) grouped Australian and New Guinean Trigona s.l. as non-aggressive, moderately aggressive and strongly aggressive. Roubik (2006), reviewing the nest defence behaviour of the Meliponini, included timid (if bees retreat within the nest entrance when approached by an intruder), aggressive (if bees attack the intruder) and tremendously aggressive (if bees use irritant chemical defence, as in Oxytrigona, or if they bite hard whilst applying sticky resin, as in Ptilotrigona). Couvillon et al. (2008) grouped stingless bees into aggressive, mildly defensive and timid. Rasmussen and Camargo (2008) grouped the Neotropical Trigona s.s. as aggressive vs. non-aggressive or docile. Knowledge of the defence behaviour of the bee species of a region is useful for Meliponiculture practices, allowing beekeepers to select suitable bee species for rearing.

It has been suggested by Camargo and Moure $(1994,1996)$ that the Chaco region is an interesting area to study speciation in Meliponini due to the shared biogeographical distribution of the three endemic Meliponini taxa: Geotrigona argentina Camargo and Moure, Paratrigona glabella Camargo and Moure, and Tetragonisca fiebrigi (Schwarz). The relationship between the woody flora and Meliponini bees in the Chaco forest is currently threatened by forest fragmentation and logging. In this scenario, beekeeping with Meliponini bees (Meliponiculture) should be a good practice for the conservation of both forest vegetation and native stingless bees. The cultural importance of the Chaquenian stingless bees was stressed by Arenas (2003). However, several biological aspects remain scarcely understood. Meliponiculture has been considered as a sustainable activity through the forests of the world due to its ecological, economic and cultural implications (Venturieri et al. 2003). 
Therefore, it can be integrated into forestry, fruit crop pollination and short cycle cultures contributing to wild plant and crop pollination, honey, pollen and wax production, and preservation of traditional knowledge about bees, as well as the conservation of this regional Meliponini fauna. To achieve an in-depth knowledge of the bionomical aspects of bees in this new meliponine beekeeping area, the present work was conducted during different seasons over a 6-year period and in several environments (natural forests and human populated areas) from six localities. In this way, it was possible to identify a wide range of bionomical features.

The bionomical features of the subtropical Meliponini bees are expected to be different from those of tropical ones, mainly due to the difference in the climate conditions of these two areas. Therefore, a regional common pattern of feeding habits, nesting and behaviour will be elucidated for the Chaquenian stingless bee species as well as the difference between these subtropical species and their co-generic tropical ones.

The aim of this study was to provide field information about flower visits, nesting substrates, nest entrance architecture and nest defence behaviour against humans for seven stingless bee species that inhabit the Chaco region. In addition, a key to identify Meliponini species by beekeepers is presented. This key is based on field aspects related to nesting substrates and nest defence behaviour from humans, which have been of interest for rearing stingless bees in other areas, such as Mexico, Brazil and Costa Rica (Nogueira-Neto 1997; Martins et al. 2004; Cortopassi-Laurino et al. 2006). Meliponiculture started only a few years ago in Argentinean tropical areas which are located at the same latitude as the Chaco forest. In these tropical areas, a greater diversity of Meliponini species occurs (Silvestri 1902; Camargo and Moure 1988; personal observation). In the Chaco region, the traditional use of Meliponini bee provisions (honey, pollen and wax) is still mainly carried out by extracting wild colonies from the forest. It is regrettable that Meliponiculture is still a rudimentary practice compared with that of tropical areas.

\section{MATERIALS AND METHODS}

\subsection{Study area}

The Chaco region consists of a large sedimentary plain covered by xerophylous and riverean forests of about 1,000,000 $\mathrm{km}^{2}$, extending north and south of the Tropic of Capricorn (23 S) over northern Argentina, western Paraguay, southeastern Bolivia and the extreme western edge of Mato Grosso do Sul state in Brazil (Prado 1993; Figure 1). The Chaco forest is a semiarid forest crossed by few active rivers and several channels from ancient rivers with gallery forests, the latter converted into savannas or shallow lakes (Adámoli et al. 1990). This forest is characterized by woody and spiny trees and shrubs, cacti, climbers and herbs; the latter are scarce during the dry season and abundant during the wet summer and moist autumn. Most melittophilous plants belong to Asteraceae, Fabaceae, Malvaceae, Solanaceae, Capparidaceae, Cactaceae, Verbenaceae, Bromeliaceae and Acanthaceae families. The Chaco climate has a strong seasonality (with summer maxima of up to $49^{\circ}$ $\mathrm{C}$ and severe winter frosts). Rainfall is $500-700 \mathrm{~mm} /$ year in the western and central parts (Dry and Transitional Chaco, respectively) with a dry period during winter and spring and a rainy period with some waterlogging during summer and autumn (Pennington et al. 2000).

\subsection{Field observations and specimen collection}

Field observations were carried out for 6 years (2003-2008) both in native forests and inhabited areas in six localities of the Chaco Province of Argentina (Figure 1), corresponding to the dry and transitional Chaco districts of the phytogeographical Chaco Province (Cabrera 1971): Juan José Castelli $\left(25^{\circ} 56^{\prime} \mathrm{S}, 60^{\circ} 37^{\prime} \mathrm{W}\right)$, Villa Río Bermejito $\left(25^{\circ} 37^{\prime} \mathrm{S}\right.$, $\left.60^{\circ} 15^{\prime} \mathrm{W}\right)$, El Espinillo $\left(25^{\circ} 24^{\prime} \mathrm{S}, 60^{\circ} 27^{\prime} \mathrm{W}\right)$, Miraflores $\left(25^{\circ} 29^{\prime} \mathrm{S}, 61^{\circ} 01^{\prime} \mathrm{W}\right)$, Reserva Provincial "Loro Hablador" $\left(25^{\circ} 27^{\prime} \mathrm{S}, 61^{\circ} 53^{\prime} \mathrm{W}\right)$ and $\mathrm{El}$ Sauzalito $\left(24^{\circ} 24^{\prime} \mathrm{S}, 61^{\circ} 40^{\prime} \mathrm{W}\right)$. Field observations of bees on flowers (flower visits) and collection of 

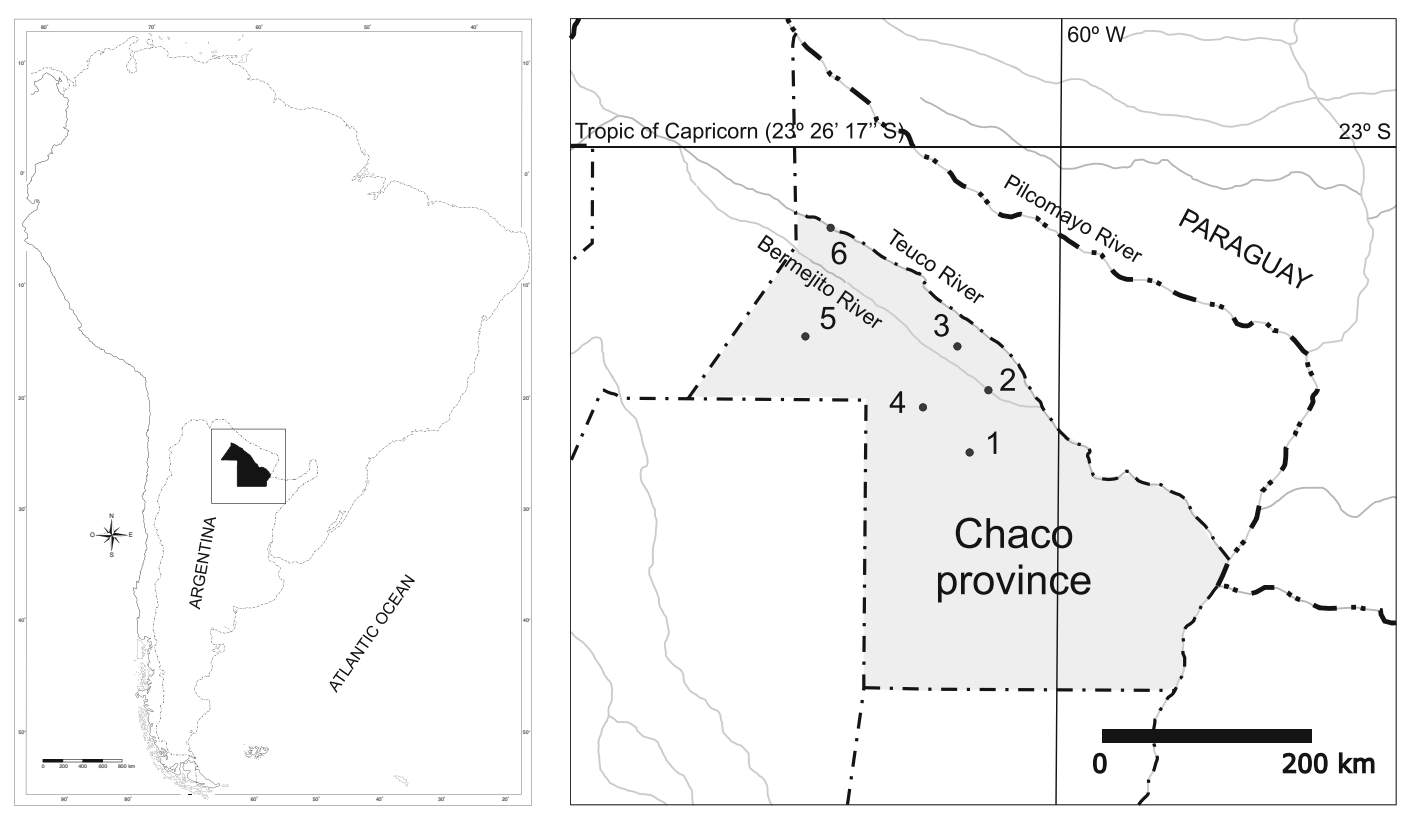

Figure 1. Location of the six sites studied in the Chaco Province, northern Argentina. 1 Juan José Castelli (25 $\left.56^{\prime} \mathrm{S}, 60^{\circ} 37^{\prime} \mathrm{W}\right) ; 2$ Villa Río Bermejito $\left(25^{\circ} 37^{\prime} \mathrm{S}, 60^{\circ} 15^{\prime} \mathrm{W}\right)$; 3 El Espinillo $\left(25^{\circ} 24^{\prime} \mathrm{S}, 60^{\circ} 27^{\prime} \mathrm{W}\right)$; 4 Miraflores $\left(25^{\circ} 29^{\prime} \mathrm{S}, 61^{\circ} 01^{\prime} \mathrm{W}\right) ; 5$ Reserva Provincial "Loro Hablador" (25⒉ $\left.7^{\prime} \mathrm{S}, 61^{\circ} 53^{\prime} \mathrm{W}\right)$; 6 El Sauzalito $\left(24^{\circ} 24^{\prime} \mathrm{S}\right.$, $\left.61^{\circ} 40^{\prime} \mathrm{W}\right)$.

bees were carried out at random on the available blossoms of each season, mainly during summer (February) and early spring (August). Samples were taken in the lower stratum and understory of the forest and open areas, i.e. lower branches of trees, shrubs and climbers ( $<2 \mathrm{~m}$ high), lower climbers and herbaceous plants, using nets and hand. Flora was associated to each bee species through these field observations (Table I). Furthermore, flower colour, relative size of flowers or dense inflorescences, massflowering degree and life form were recorded for each plant species (Table I). Mass-flowering degree was characterized taking into account the ratio between the flowering surface and the canopy surface at the moment of the flowering peak for each plant species and was classified as low $(<1: 4)$, moderate (1:4 to $1: 2)$, high (1:2 to $3: 4)$ and very high $(>3: 4)$, following Ramalho (2004). Nests were intensively searched for and visually located within the forest, forest edges, pathways, and adobe and brick walls, in a ratio of up to $3,000 \mathrm{~m}$ per site. Due to the difficulty of finding nests of ground-nesting and small-entrance bee species, the location of some nests was done with the help of local people. Nesting substrates, their living status (in woody substrates), relative trunk size and the height of the nest entrance were recorded (Table II), and some bees from nest entrances were hand-collected for further identification. Nest entrances were photographed and many were taken for further description (Table III and Figures. 2, 3, 4 and 5). Bees were identified by Arturo Roig Alsina and deposited in the Entomology Collection of the Museo Argentino de Ciencias Naturales "Bernardino Rivadavia”, Buenos Aires, Argentina. Nesting and foraging plants were collected, pressed into herbaria, identified by the author and deposited in the Herbaria of the Museo of La Plata, Buenos Aires, Argentina. Nesting plants are listed in alphabetical order of their families (Table II).

\subsection{Nest defence behaviour from humans}

To describe the nest defence behaviour from humans, the following categories are used: 


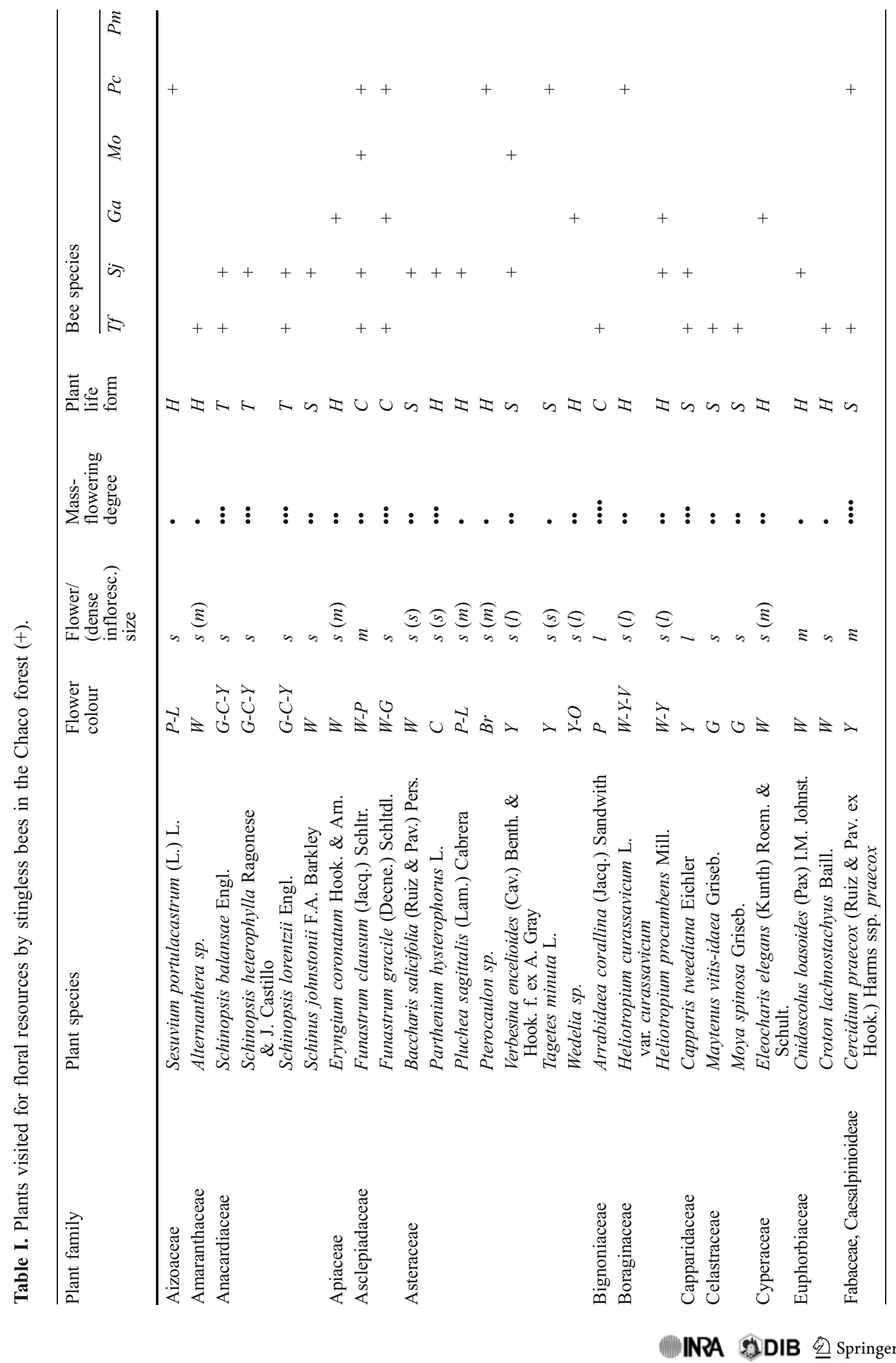




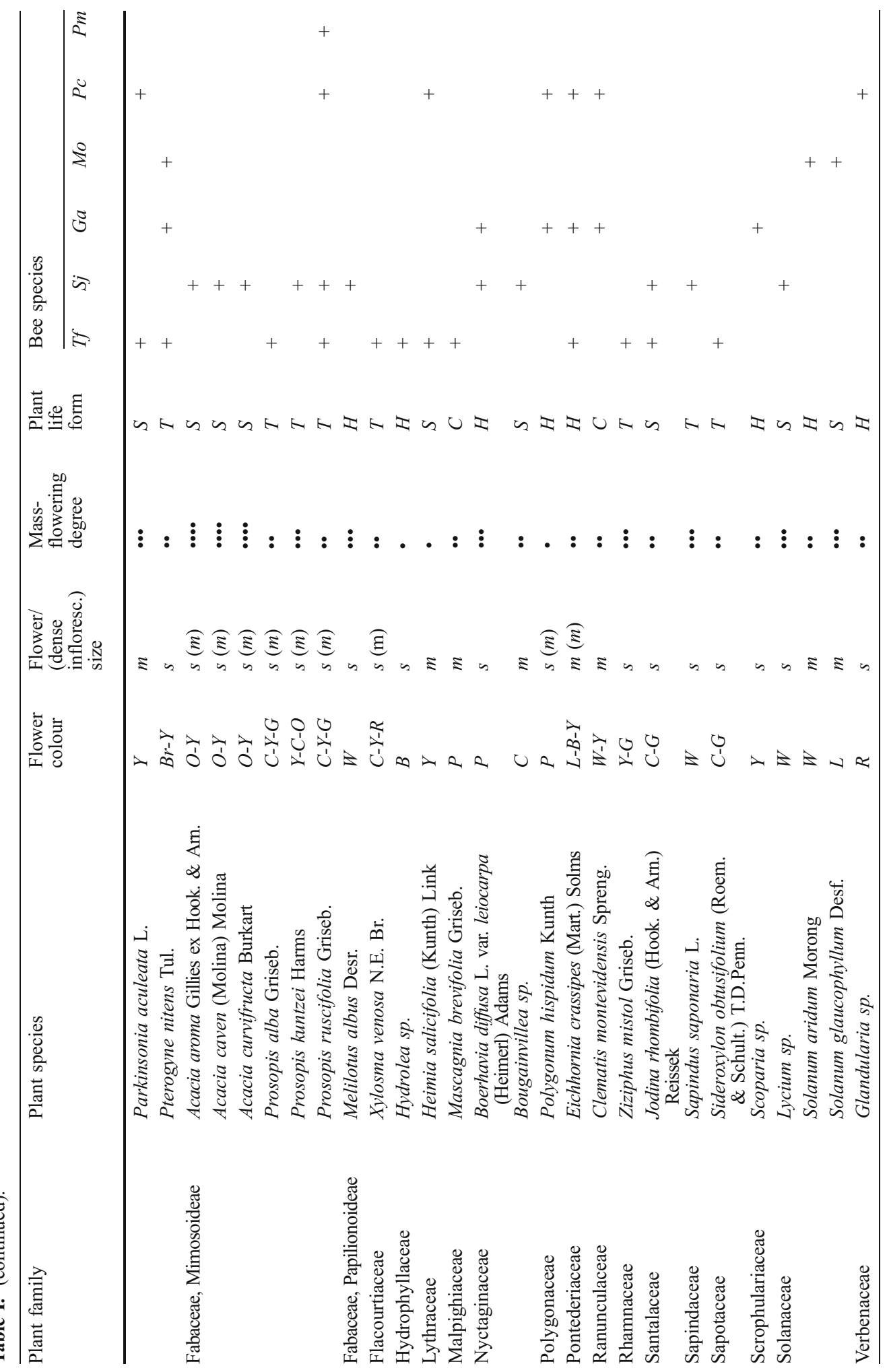


Aggressive are those species that attack an intruder when approaching the nest, catching a bee or touching the nest entrance. Docile are those species that do not attack an intruder when approaching the nest, catching a bee or touching the nest entrance. Docile species are classified into timid and non-timid.

Timid bees retreat into the nest entrance or observe an intruder from the nest entrance when approaching the nest and usually suspend or decrease their flying activities. Non-timid bees continue their flying activities, ignoring the presence of the intruder.

Tremendously aggressive bees are those that bite intensively or apply caustic secretions, such as Ptilotrigona, Tetragona, several Trigona s.s. and Oxytrigona (Camargo and Pedro 2004; Roubik 2006; Rasmussen and Camargo 2008).

\section{RESULTS}

\subsection{Bee diversity, flower visits, nesting substrates, nest entrance architecture and nest defence behaviour}

Seven species were recorded from the Chaco Province: T. fiebrigi (Schwarz), Scaptotrigona jujuyensis (Schrottky), G. argentina Camargo and Moure, Melipona orbignyi (Guérin), Plebeia catamarcensis (Holmberg), Plebeia molesta (Puls) and Lestrimelitta chacoana Roig Alsina.

The flower visit method allowed the identification of a total of 55 melittophilous plant species from 28 families (Table I). The flowering spectrum included diverse plant life forms, flower colours and sizes, and mass-flowering degrees. The most commonly visited plants were of herbaceous habits (22 species), predominantly had flowers of white/creamy to yellowish colour (36 species), with small-sized flowers (42 species) and were of moderate mass-flowering degree (25 species; Table I). The bees $T$. fiebrigi, $S$. jujuyensis and $P$. catamarcensis were found foraging on several species of diverse habits. However, G. argentina and $M$. orbignyi were found mainly on herbs. For $P$. molesta, only one flower visit was observed on the shrub-tree Prosopis ruscifolia Griseb. 
Substrate type, woody plant living status, relative size of trunks or branches, and height of nest entrances were recorded from a total of 94 nests of seven stingless bees (Table II). All nests were located inside preexisting cavities of both natural and artificial substrates. Natural substrates included living and dead tree and woody shrub trunks (for six bee species, $85.11 \%$ of the total nests) and the ground (only for $G$. argentina, 6.38\%). Artificial substrates included brick walls and window frames (only for $P$. catamarcensis, 8.51\%). Taking into account all wood-nesting bee species, most nesting substrates were living in woody trunks $(90 \%$, only $10 \%$ were dead trunks) and large-sized trunks (77.78\%, medium-sized were $20.83 \%$ and small-sized trunks only $1.39 \%$ ). Nest entrances were found mainly at the trunk base $(0-0.10 \mathrm{~m}$ high, 65\%), followed by nests at different heights of the main trunk $(>0.10-5 \mathrm{~m}, 30 \%)$ and on branches $(5 \%)$. The most important woody plant species providers of nesting substrates were Bulnesia sarmientoi Lorentz ex Griseb. (16.25\%), Aspidosperma quebrachoblanco Schldtl. (12.5\%), Schinopsis balansae Engl. (10\%), Schinopsis lorentzii Engl. (10\%) and Prosopis alba Griseb. (7.5\%).

Most nests were recorded for T. fiebrigi ( $n=$ $36,38.3 \%)$ and S. jujuyensis $(n=25,26.6 \%)$, followed by $P$. catamarcensis $(n=13,13.83 \%)$, the two former species found in forests and the latter commonly found in inhabited areas (Table II).

Nests of $G$. argentina were built in hollows of abandoned ant nests (possibly Atta species), which are abundant in the dry Chaco plain. Depth from surface to nest cavity varied from 0.5 to approx. $2.0 \mathrm{~m}$. Nests were established in open fields such as pathways and "cardonales" of the Stetsonia coryne (Salm-Dyck) Britton and Rose cactus or under the shade of trees either in the forest or isolated.

Nest entrances were diverse among the Meliponini bees of the Chaco region, and they differed in building materials, colour, size and shape (Table III). Cerumen was used by most species, but only mud was used by $M$. orbignyi and mud mixed with sand and cerumen by $P$. molesta.
Small cryptic entrances were found for $G$. argentina (Figure 2) and the two Plebeia species (Figure 3), and medium-sized cryptic ones for $M$. orbignyi. The remaining bee species had small- to medium-sized, yellowish/orange/brownish cerumen tubes with several guards flying around it (T. fiebrigi; Figure 4), medium-sized, brownish cerumen tubes (S. jujuyensis; Figure 5), or large, black cerumen tubes with digitiform lateral projections (L. chacoana).

Light-coloured cerumen (yellow orange to brown) was found in nest entrances of $T$. fiebrigi only, whilst dark brown to black ones were present in $S$. jujuyensis, $G$. argentina, $P$. catamarcensis and L. chacoana (Figures. 2, 3, 4 and 5). Non-cerumen entrances were found in M. orbignyi, which uses mud that varies in colour according to the soil type, and in some nests of $G$. argentina. Entrances of $P$. molesta were built from different mixtures of mud and sand in a dark brown cerumen matrix.

The most common shape of nesting entrance was the tube-like structure, which was horizontal or arched upwards in T. fiebrigi (Figure 4), $P$. catamarcensis (Figure 3), S. jujuyensis (Figure 5) and L. chacoana. A ring (equivalent to a very short tube) was found for some nest entrances of $G$. argentina and in the mud-sand entrance of the wood-nesting species P. molesta. Radiating mud ridges were found only in $M$. orbignyi. Digital projections in the lateral and basal parts of the tube-like entrance were found only in L. chacoana. Sculptured structures were not present in the remaining species with tubelike nest entrances.

The entrance of one of the nests of $L$. chacoana was closed with cerumen, indicating that it was a new nest. Surprisingly, another nest was found hosted in a previous year nest of $T$. fiebrigi, inferring the cleptobiotic habit of $L$. chacoana and indicating one of its host species. A heap of pollen garbage deposited underneath the nest entrance is a characteristic of $L$. chacoana nests.

Nest defence behaviour against humans included docile timid bees (three species: G. argentina, M. orbignyi and L. chacoana); docile non-timid 


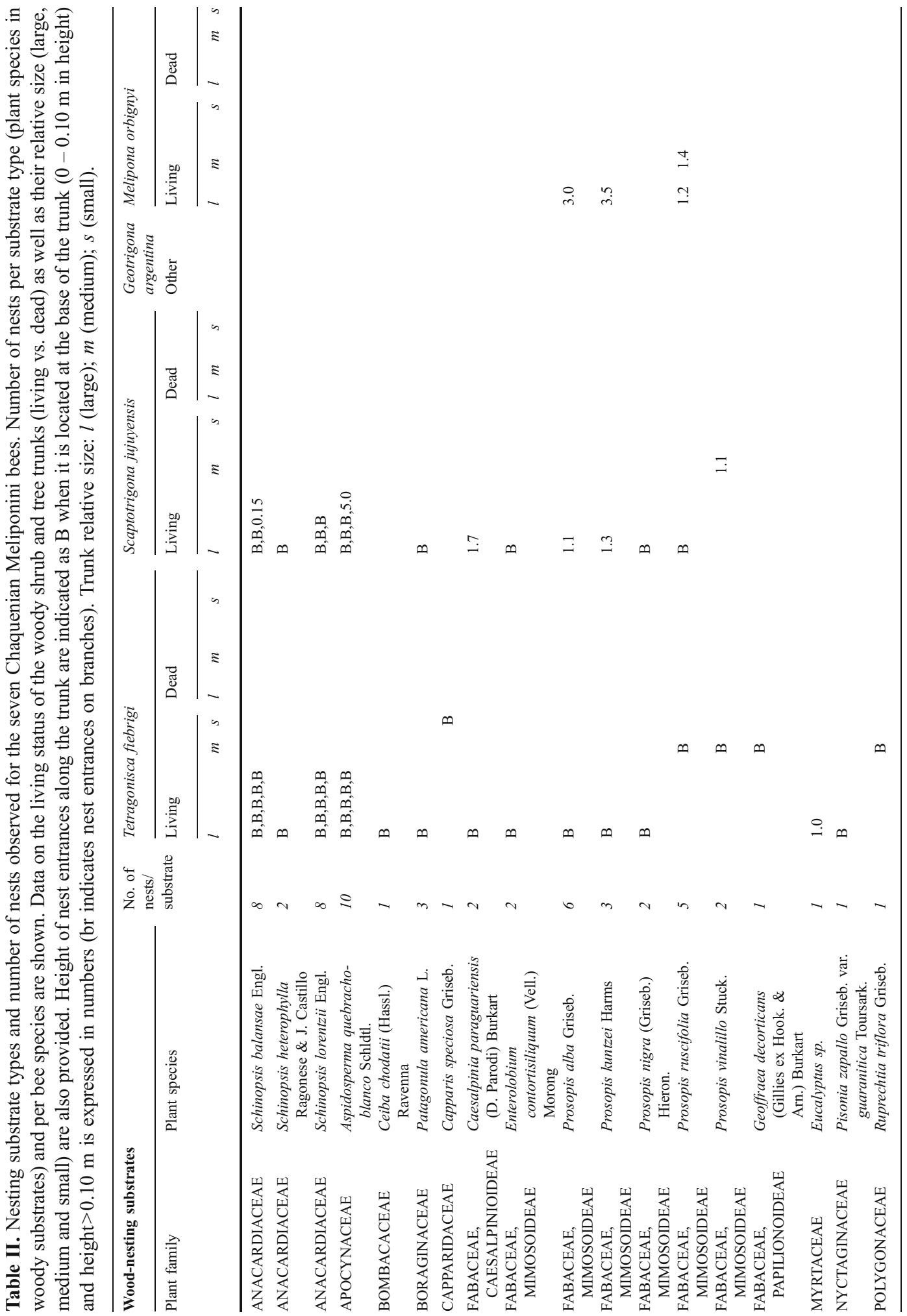




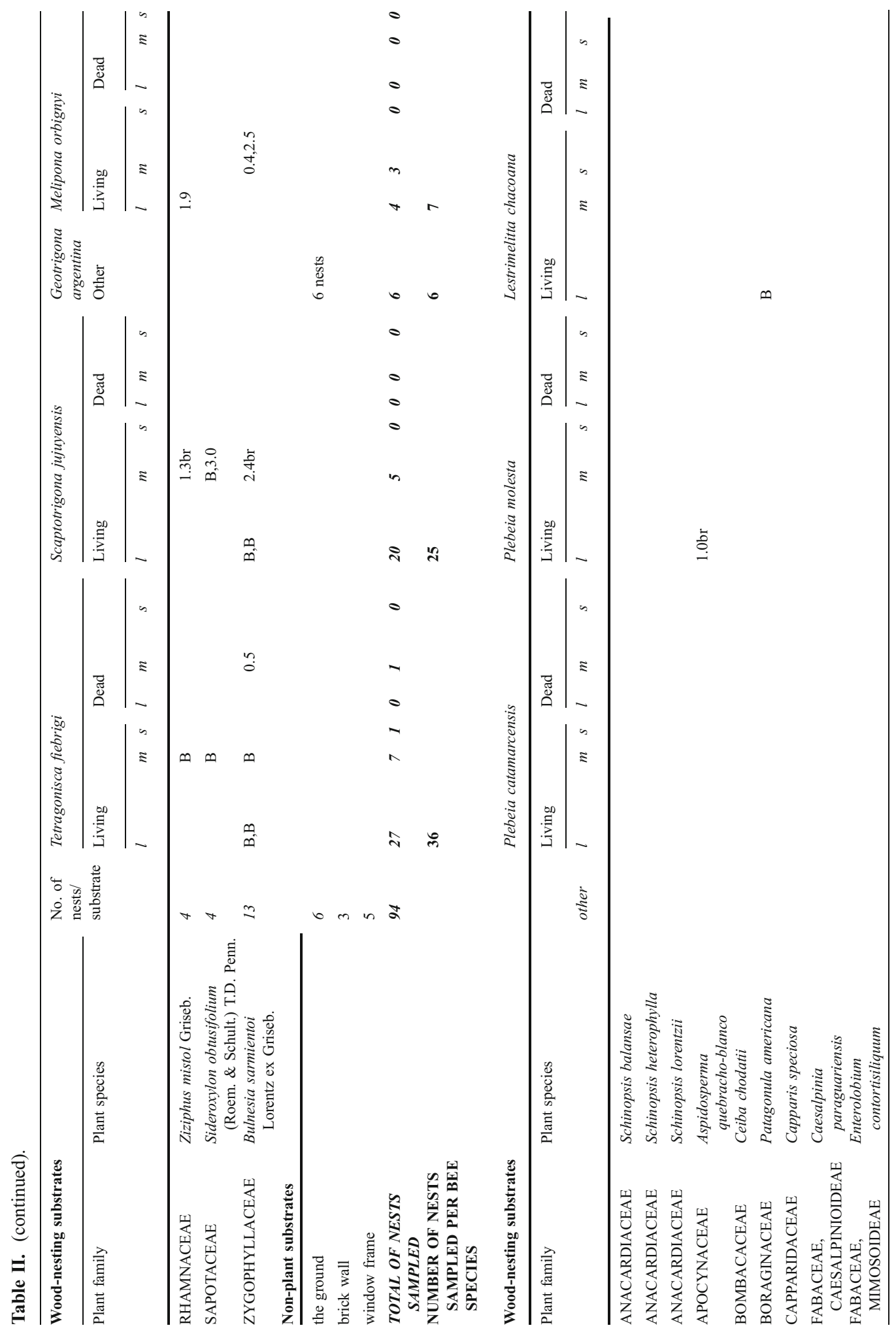




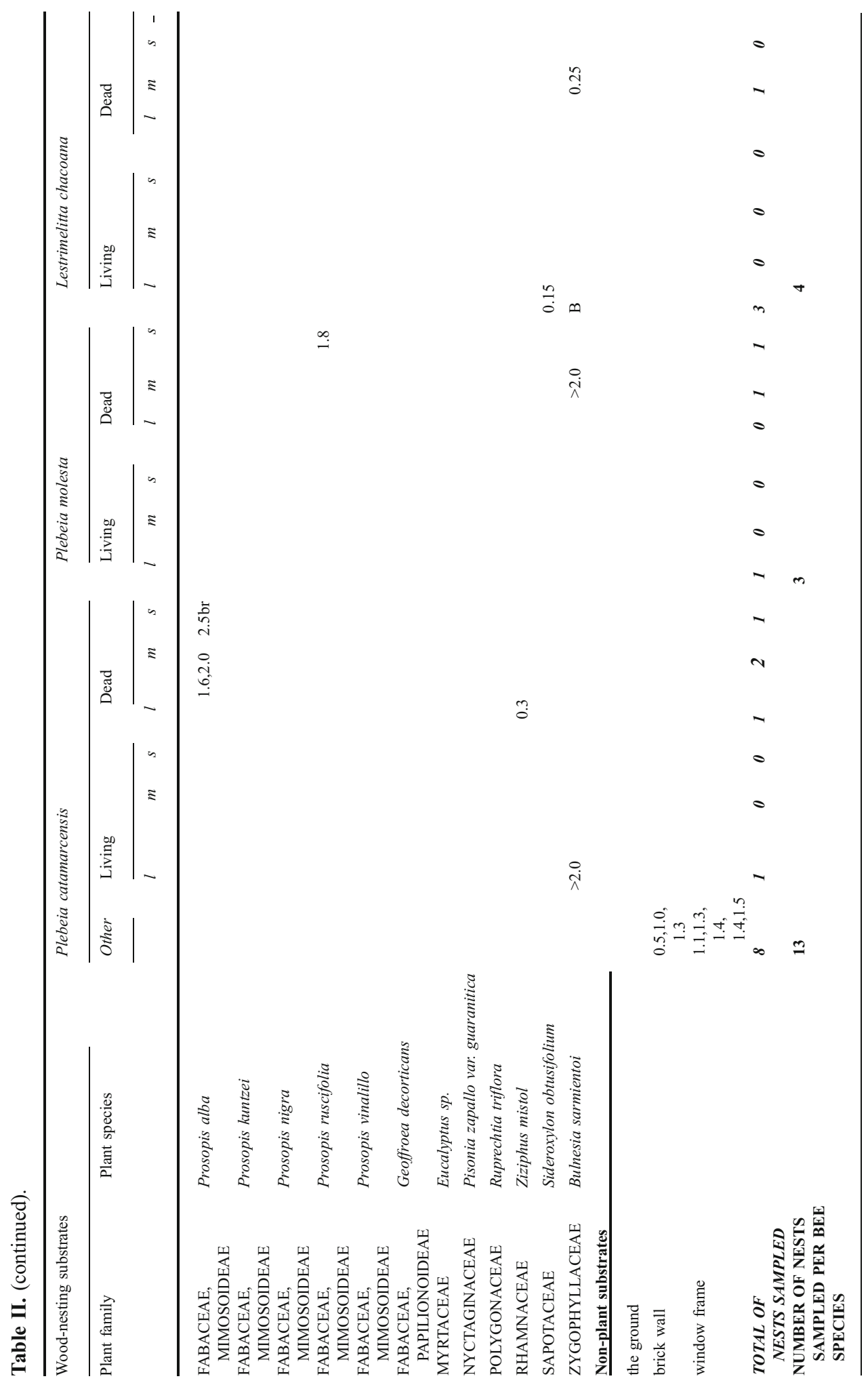




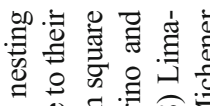
을 登 을

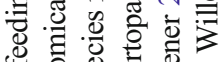
응 施.

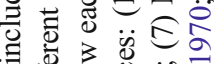

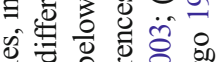
을

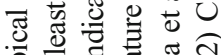

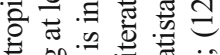

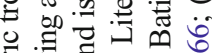

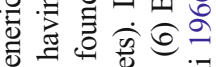
on

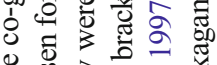

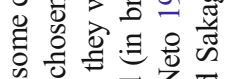

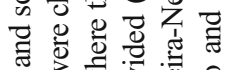
के . 0
0
0

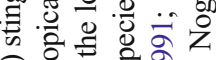
可

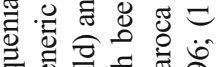
릉

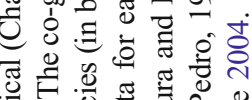

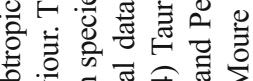

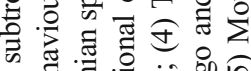

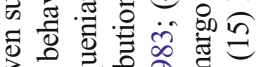
舟

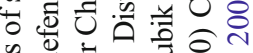

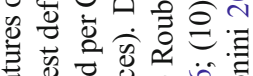

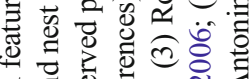

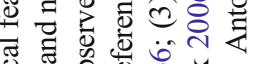

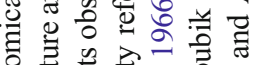

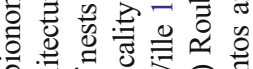

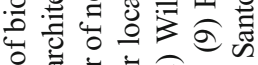

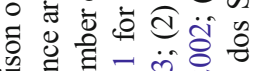

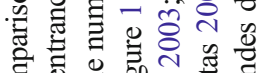

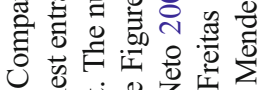

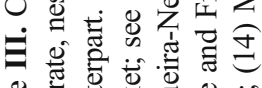

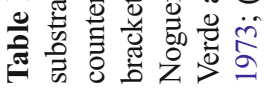

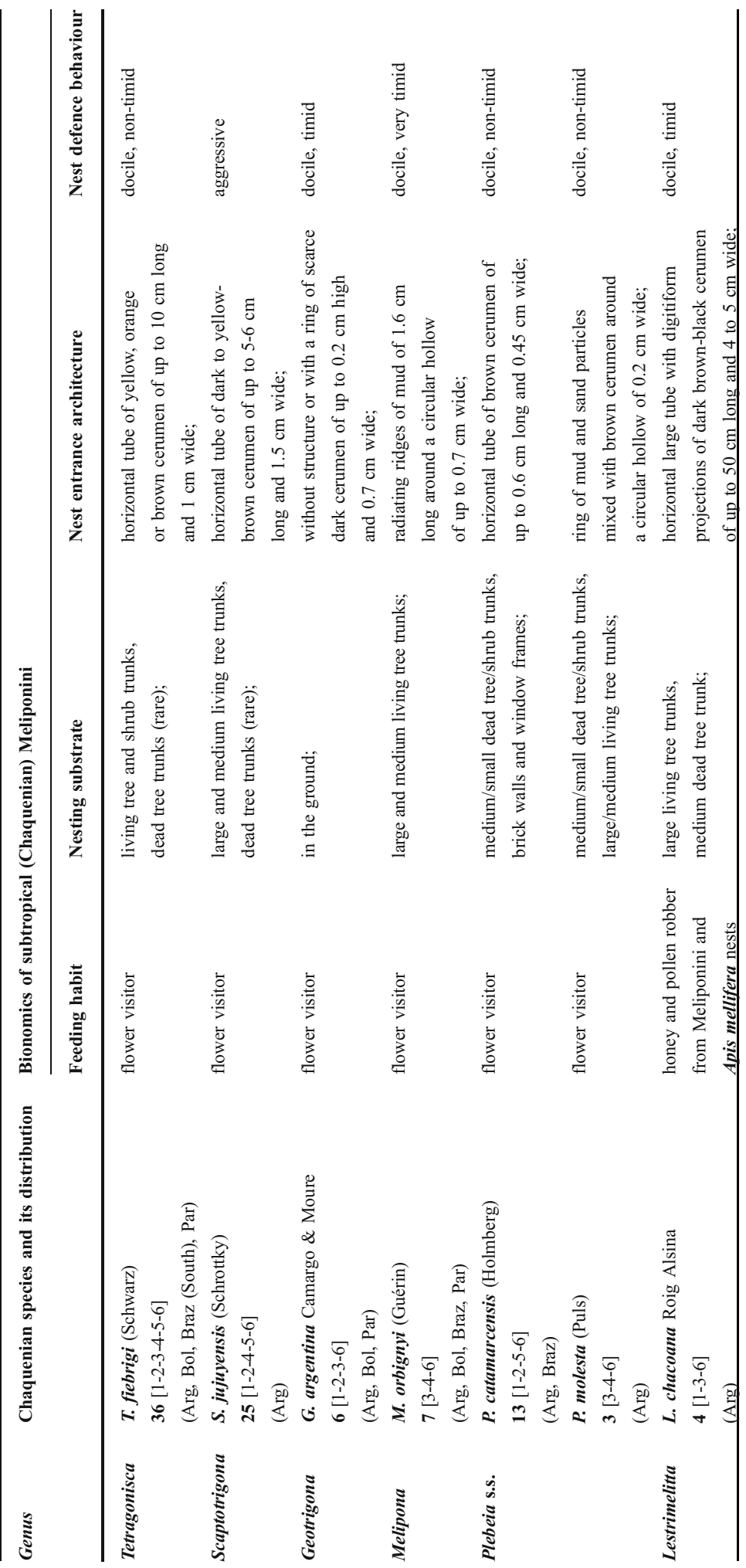




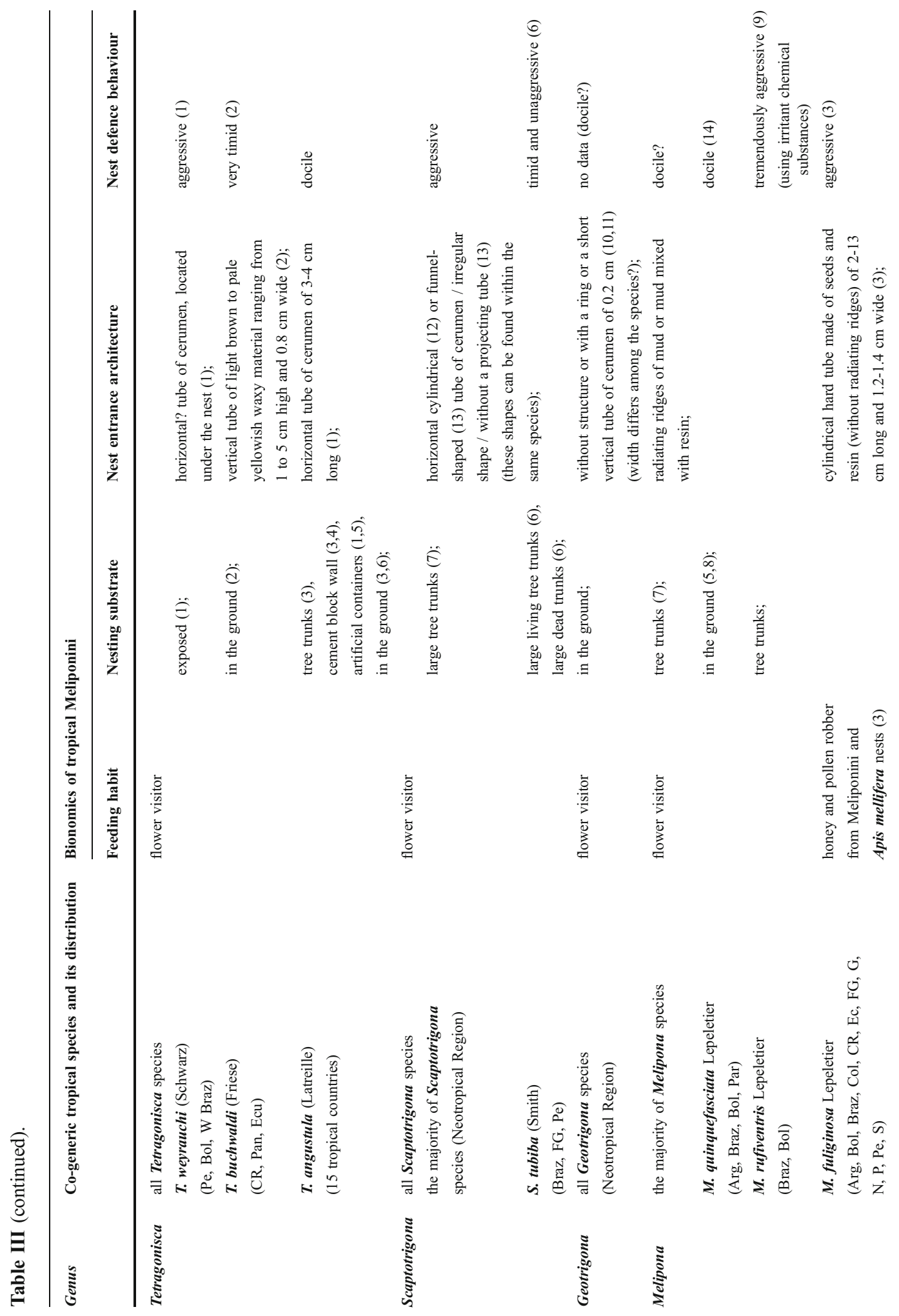

INPA SDIB 咀 Springer 


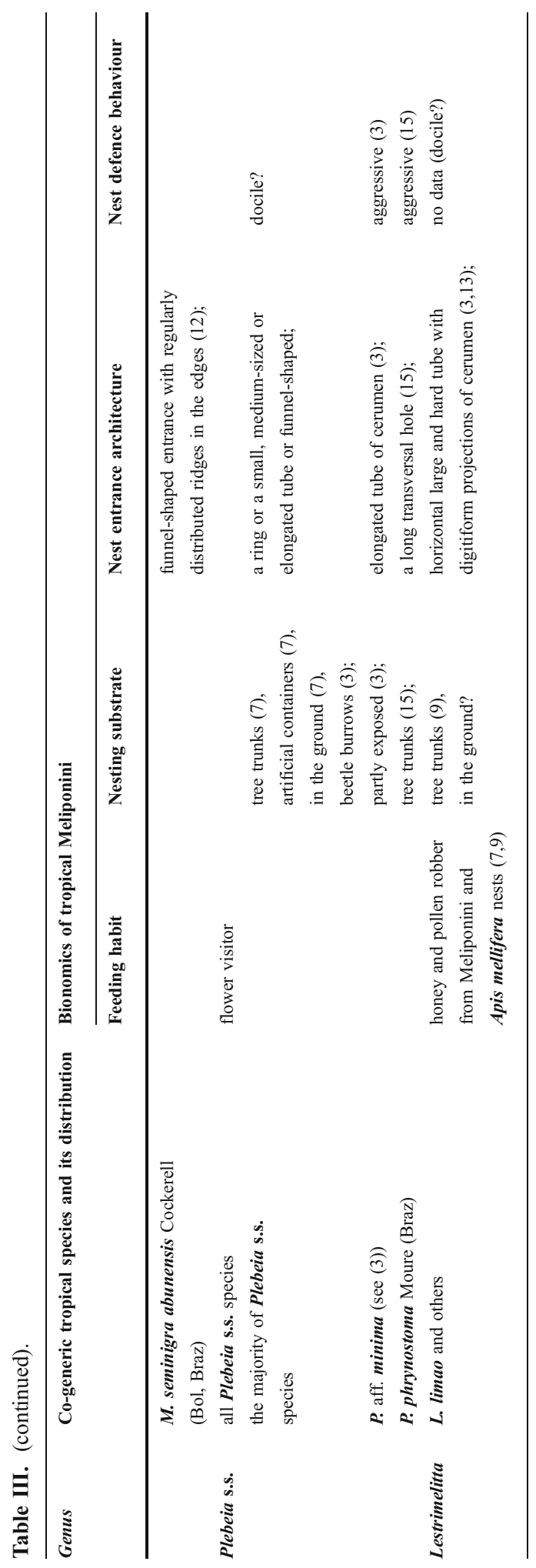

bees (three species: T. fiebrigi, P. catamarcensis and $P$. molesta); and aggressive ones (one species: $S$. jujuyensis). Tremendously aggressive bee species were not found in the study area.

The defence behaviour of S. jujuyensis is as follows: When the nest entrance is touched or a bee is caught by an intruder, the bees attack. Nest defence behaviour includes biting mainly on the head, cutting hairs, entering the nose and ears, and biting the skin, eyelids and lips. Defensivity involves the recruitment of other bees of the colony. For T. fiebrigi, $G$. argentina and $M$. orbignyi, if a human intruder opens the nest, only some bees become mildly aggressive, biting the skin and hair of the intruder.

\subsection{Key for field identification of stingless bees of the Chaco forest based on nesting substrate and nest defence behaviour}

In order to facilitate the identification of the stingless bees that inhabit the dry and transitional Chaco forest by beekeepers, researchers and any other interested person, a present key is supplied using nesting substrate and nest defence behaviour features.

A-Without or with poor flight activity, several bees look at the observer, stand in the nest entrance or retreat into the interior. No guard bees performing hover flights in the front of the nest entrance. Non-aggressive bees. Nests in tree trunks (and possibly in the ground). Large nest entrance, variable in length, elliptic hole of 2- to $5-\mathrm{cm}$ width. Bees lemon-scented....

Lestrimelitta chacoana

AA-Bees with regular flight activity or suspended only if a human intruder approaches the nest. Nest entrances smaller, elliptic hole $2 \mathrm{~cm}$ wide or less. Bees non-lemonscented. ..B

B-Aggressive bees attack an intruder when touching the nest entrance or catching a bee. Nest defence behaviour includes biting mainly on head, biting of skin, eyelids and lips, cutting of hair, and entering nose and ear cavities. Bees coconut-like-scented (Figure 5). 


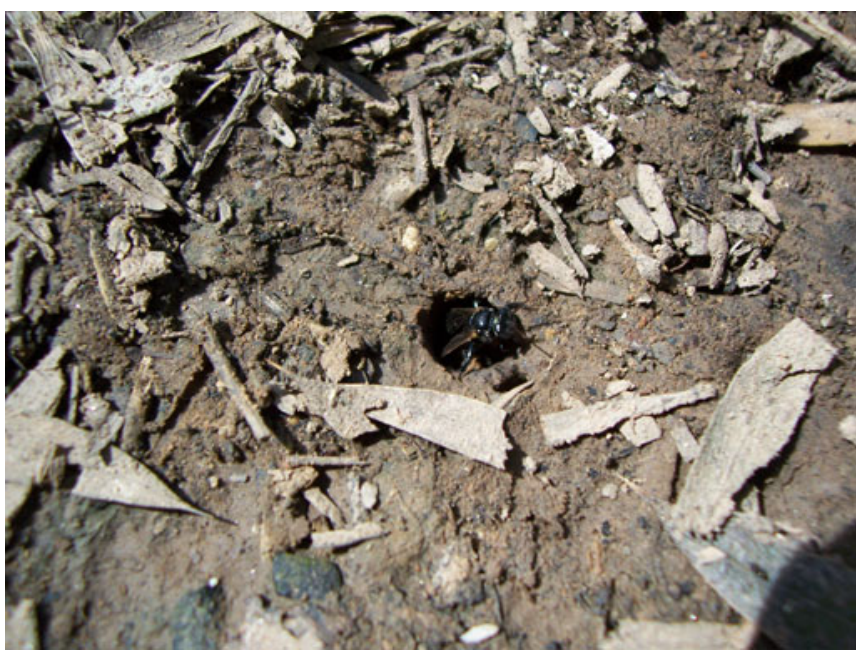

Figure 2. Nest entrance of the ground-nesting stingless bee G. argentina. A worker coming out of the cryptic and unornamented nest entrance is observed. The entrance of this particular nest lacks cerumen.

BB-Docile bees............................... $\mathrm{C}$-Nesting in the ground. Black bees (Figure 2). ..Geotrigona argentina

$\mathrm{CC}$-Nesting in tree trunks or buildings (brick and adobe walls) ..D

D_Timid bees (bees avoid flight activity when an intruder approaches the nest within $5-10 \mathrm{~m})$. Bees emitting buzzing sound. Nests frequently found in living tree trunks.
Robust bees. Distinct yellow bands on black abdomen. Melipona orbignyi

DD - Non-timid bees (bees apparently ignore intruders, their flight activity continues). Bees not emitting buzzing sounds. Various nesting substrates. Small bees. Abdomen without yellow bands.............................................E

E-Some guards in hover flight in front of the nest, at about $15 \mathrm{~cm}$ off the nest entrance.

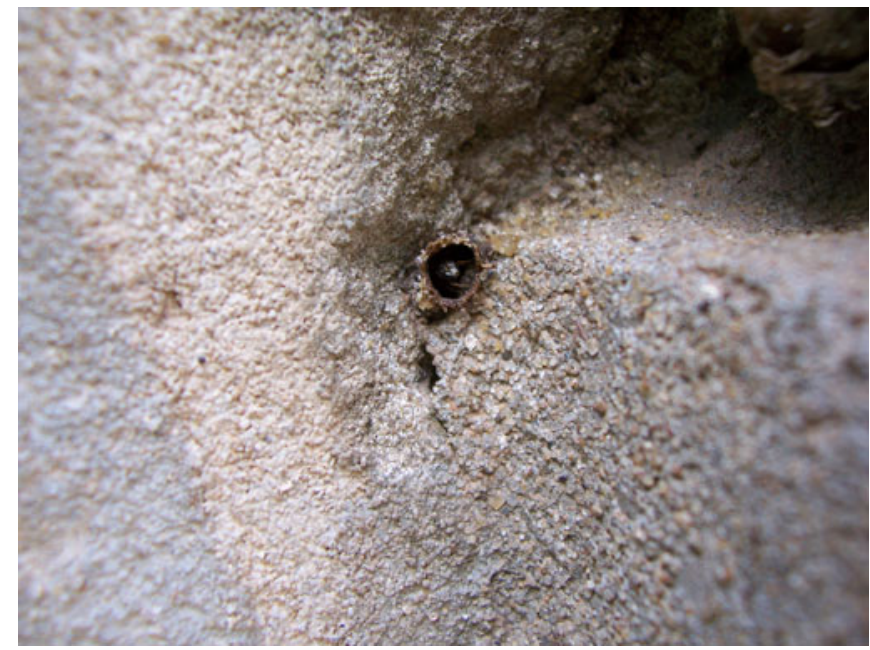

Figure 3. Nest entrance of $P$. catamarcensis in a brick wall substrate. The small and cryptic tube-like entrance is made of cerumen. 


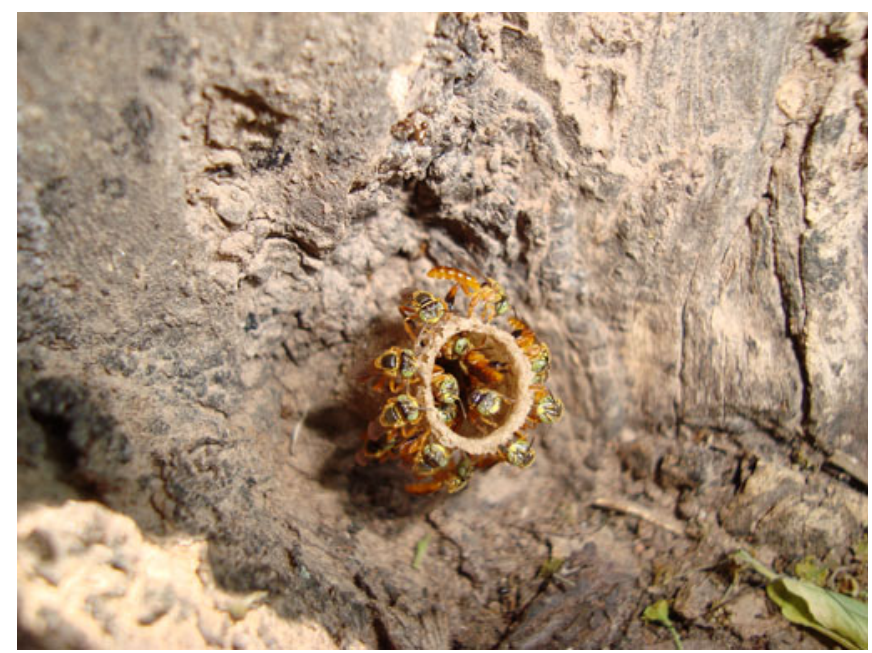

Figure 4. Nest entrance of T. fiebrigi on the base of a medium-sized living trunk of Ziziphus mistol. The entrance consists of a medium-sized tube of light cerumen. This is a docile and non-timid stingless bee.

Foragers regularly fly in and out of the nest. Nests are frequently found in living tree trunks, rare in dead tree trunks or brick walls. Slim bees, with elongated abdomen (Figure 4) Tetragonisca fiebrigi

$\mathrm{EE}$ - No bees flying in hover position in front of the nest, only one to three bees inside the nest entrance (Figure 3). Nests frequently found in dead tree trunks or brick walls, rare in living tree trunks. Very small bees, with short abdomen

Plebeia catamarcensis and Plebeia molesta

\section{DISCUSSION}

\subsection{Flower associations of Meliponini}

The relationship of stingless bees with certain plant families has been reviewed by Ramalho et al. (1990) for Neotropical habitats. They found

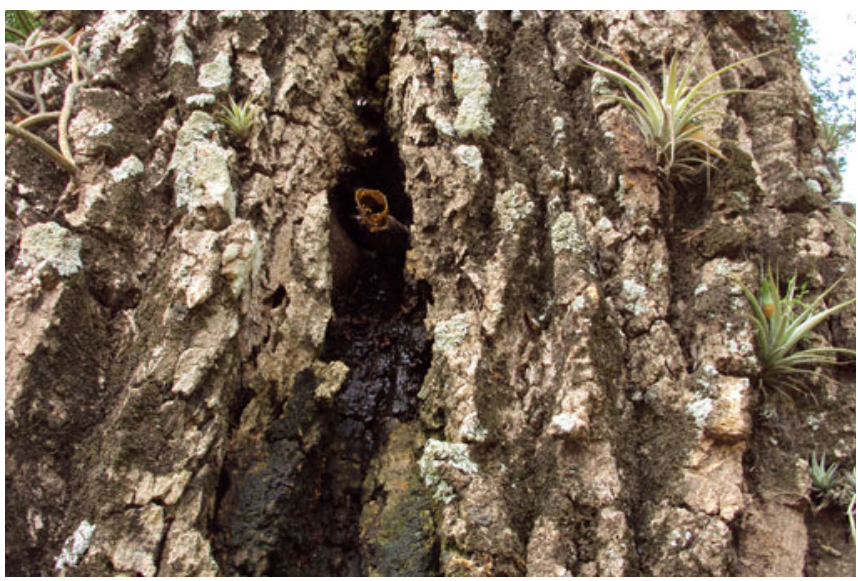

Figure 5. Nest entrance of $S$. jujuyensis located $5 \mathrm{~m}$ high along a large living tree trunk of $A$. quebrachoblanco. Incoming workers carrying pollen on their corbiculae can be seen. 
that the main pollen and nectar sources are among plant families which are best represented in these habitats: Anacardiaceae, Arecaceae, Asteraceae, Euphorbiaceae, Fabaceae, Lamiaceae, Melastomataceae, Moraceae, Myrtaceae, Rubiaceae and Solanaceae. In the subtropical dry and transitional Chaco forest, these families are also abundant (except for Melastomataceae and Myrtaceae) and dominated by Asteraceae and Fabaceae. In the present work, field observations of bees on flowers allowed the identification of the different plant families visited by the six flower-visiting stingless bee species of the Chaco forest. These observations showed that Meliponini bees were also abundantly found within the most diverse plant families of this area, such as Fabaceae (Mimosoideae and Caesalpinioideae) and Asteraceae, followed by Asclepiadaceae and Anacardiaceae (Table I).

As Meliponini are generalist bees forming large perennial colonies, they have to collect large quantities of pollen and nectar as supplies. For the success of beekeeping, beekeepers should promote the reforestation and maintenance of the most productive visited plant species. Beehives should be located in or near forests where the surrounding vegetation may supply their basic feeding needs.

\subsection{Chaquenian Meliponini species}

\subsubsection{Flower visits}

In spite of the fact that only qualitative data were obtained for flower visits, it was possible to arrive to the following conclusions: The broadest spectrum of flower visits was detected for T. fiebrigi and S. jujuyensis species (Table I), possibly due to the fact that they are either the most abundant species in the studied sites or do not have stratum preferences in the forest. Many studies done in Brazil on floral resources foraged by Tetragonisca angustula have shown that this is a highly polylectic bee, with Euphorbiaceae, Moraceae, Fabaceae and Myrtaceae being the main associated families (Imperatriz-Fonseca et al. 1984; Carvalho and
Marchini 1999). In the Argentinean Yungas mountain forest, the nectaripherous plants foraged by $T$. fiebrigi (as T. angustula Latreille) included mainly Fabaceae (Mimosoideae), Asteraceae and Myrtaceae (Flores and Sánchez 2010). In the present study, the main flower resources for T. fiebrigi were from the Fabaceae family (Caesalpinioideae and Mimosoideae subfamilies).

The genus Scaptotrigona has been found associated with Fabaceae (Mimosoideae), Myrtaceae, Asteraceae, Euphorbiaceae and Sapindaceae (Ramalho 1990; Marques-Souza et al. 2007). Herein, the number of field observations for S. jujuyensis on flowers was relatively high, possibly due to the high abundance of nests in the region, the large number of workers in the colonies and its group-foraging recruitment capability. However, it is possible that its foraging activity is concentrated in the upper strata of trees, as was denoted for Scaptotrigona bipunctata (Lepeletier; for more than $80 \%$ of the individuals) in the tropical Atlantic Rainforest of Brazil, being rarely found in the lower stratum (Ramalho 2004).

For Geotrigona species, the floral spectrum is only known for $G$. argentina in the Argentinean dry Chaco forest, with the main pollen sources being in Fabaceae (Mimosoideae), Simaroubaceae, Celastraceae and Capparidaceae, and the nectar sources in Fabaceae (Mimosoideae), Rhamnaceae, Capparidaceae, Celastraceae and Nyctaginaceae plant families (Vossler et al. 2010). Contrary to these tree and shrub food sources, many herbaceous plants were recorded in flower visits of $G$. argentina. Thus, it is possible that this bee species has no stratum preference.

The genus Melipona has been associated with families differing from those of the remaining Meliponini genera, including Fabaceae, Solanaceae, Melastomataceae, Euphorbiaceae, Myrtaceae, Asteraceae, Anacardiaceae, Sapindaceae and Convolvulaceae (KleinertGiovannini and Imperatriz-Fonseca 1987; Ramalho et al. 1989, 2007; Antonini et al. 2006). Considering the scarce number of flower visits recorded for $M$. orbignyi, it could be 
possible that its foraging activity is concentrated in the upper strata of the forest. On the other hand, a low local abundance of nests in the sampled sites could account for the poor number of flower visit records.

Plebeia is considered a generalist bee associated with Anacardiaceae, Arecaceae, Balsaminaceae, Fabaceae, Moraceae, Myrtaceae and Solanaceae plant families (Ramalho et al. 1985; Carvalho et al. 1999). Ramalho (2004) reported that the foraging distribution of Plebeia droryana (Friese) was unpredictable in the canopy of the tropical Atlantic Rainforest. In this study, $P$. catamarcensis visited several herbaceous plants. This may be related to the non-strata preference hypothesis suggested by Ramalho (2004) for P. droryana. For P. molesta, only a single flower visit was recorded.

Lestrimelitta is a robber stingless bee genus (Schwarz 1948; Sakagami and Laroca 1953); therefore, no flower visits were recorded for $L$. chacoana. Lestrimelitta species from other areas are known for robbing pollen and honey, as well as wax and resin, from nests of the other Meliponini genera, such as Tetragonisca and Plebeia (Sakagami and Laroca 1953). Thus, Lestrimelitta species are considered a threat to Meliponiculture. In the Chaco forest, alternative feeding habits such as hemipterophily and necrophagy were not recorded, and they seem to be found only in tropical areas (Roubik 1982, 1989; Camargo and Pedro 2002). Therefore, the production of honeydew honeys and the addition of non-hygienic ingredients should be absent in honeys obtained through Chaquenian Meliponiculture.

A large number of records of flower visits were recorded for herbaceous and shrubby species, possibly because samples were taken in the lower strata of the forest. The high abundance of visits on flowers with predominantly white/creamy to yellowish colouration can be explained by the fact that they are the typical bee flowers and are dominant in this region. Small-sized flowers and moderate mass flowering are also known as the most preferred flower syndromes of Meliponini bees in tropical areas (Ramalho 2004). Notwithstanding, plants of various life forms and flower features constituted the broad diet of the Chaquenian stingless bees. The flower visit collection method allowed the identification of plants supplying pollen and nectar to Meliponini bees in the Chaco forest. However, these resources could not be distinguished by using this method. To identify pollen and nectar plant sources, pollen analysis of bee nest provisions need to be done. Furthermore, a broader spectrum of plants (including those found in the upper strata or inaccessible sites) should also be recorded.

\subsubsection{Nesting substrates}

In the dry and transitional Chaco forests, large living tree trunks were the main nesting substrates of $T$. fiebrigi, S. jujuyensis, $M$. orbignyi and L. chacoana (Table II). Due to the fact that the largest trees are logged, mainly these bee species are being threatened. In the forest, $P$. catamarcensis and $P$. molesta were abundant in small- to medium-sized dead trunks or dead branches of living shrubs or trees. However, in inhabited areas, $P$. catamarcensis seemed to prefer small cavities in brick walls and window frames. The ground-nesting stingless bees were $G$. argentina (and possibly the cleptobiotic L. chacoana, when parasitizing $G$. argentina; Arenas 2003). In tropical areas, nests of T. fiebrigi are commonly found in brick walls (Taura and Laroca 1991). However, nesting in this substrate was not denoted in inhabited areas of the Chaco region. Most Scaptotrigona species have been found nesting in living tree trunks (Michener 2007), as observed for $S$. jujuyensis (Tables II and III). M. orbignyi built nests in the forest and seemed to be rare in inhabited areas. Some Melipona species appeared to be affected by deforestation. They were present mainly in areas where the forest was more intact (Brown and Albrecht 2001) and preferred living in tree trunks for nesting (cf. Roubik 1989).

The number of plant species providing nesting substrates was high for T. fiebrigi and $S$. jujuyensis and low for $M$. orbignyi, $L$. 
chacoana, P. molesta and P. catamarcensis. This difference is due to the difficulty in finding species with cryptic and small nest entrances and those showing timid defence behaviour of workers when approached by an observer. Moreover, the cleptobiotic habit of L. chacoana may be an explanation for its rarity. In the Chaco region, other nesting substrates such as active social insect nests (ants, termites, wasps) or exposed (aerial) and semi-exposed nests were not present, perhaps due to the difficulty in controlling internal nest temperature during low-temperature and frost periods, as was shown by Cortopassi-Laurino and NogueiraNeto (2003) for Tetragonisca weyrauchi in the state of Acre in Brazil.

Knowledge on nesting substrates is of great interest to Meliponiculture (Cortopassi-Laurino et al. 2006) as it discloses information about the size, thickness and other qualities of the wood required for constructing beehives. Such information is helpful for the successful rearing of wild bee species that nest in tree hollows. The Chaco is a woodland area with a considerable amount of trees providing nesting cavities for Meliponini bees. A local population of wild nesting bees is important for ensuring the genetic diversity of any of these species managed under meliponiculture conditions, especially as colonies that have become sick and/or died during beekeeping need to be replaced. Nonetheless, species with subterranean nesting habits are difficult to maintain in hives (Nogueira-Neto 1997; Cortopassi-Laurino et al. 2006).

\subsubsection{Meliponini bees and the woody flora of the Chaco forest}

Some plant species provided both flower resources and nesting substrates to the bees. From a total of 55 plant species providing floral resources, 32 were herbs incapable of providing nesting substrates. From a total of 19 woody plant species providing nesting substrates, eight also provided flower resources; the remaining were melittophilous trees and shrubs that were not recorded in the flower visits. Probably, the absence of flower visits on certain trees, climbers and shrubs could be related to the foraging preference of the upper forest strata by Meliponini bees. However, it is possible to observe a straight relationship between stingless bees and the woody flora of the Chaco forest (Tables I and II). Due to the fact that this association is threatened by deforestation, Meliponiculture could be a good economic reason and sustainable practice to ensure the conservation of bee and plant species and their interaction in the Chaco forest.

\subsubsection{Nest entrance architecture}

The most commonly found nest entrances among the Chaquenian stingless bees were cryptics and were characterized by the presence of unornamented tube-like shapes, made of cerumen and small- to medium-sized. They are the simplest nest entrance architecture when compared with tropical species, including with their co-generics (see Table III).

\subsubsection{Nest defence behaviour}

Only aggressive (one species) and docile (timid and non-timid) behaviour of bees was found in the study area. Tremendously aggressive stingless bees were not found in the area. The stingless bees of the dry and transitional Chaco forest could be identified by means of their nest defence behaviour and nesting substrate. The presence of docile species and the absence of tremendously aggressive species favour the rational management of beehives in the Chaco region. All flower-visiting bee species should be used in Meliponiculture and crop pollination.

\subsubsection{Stingless bee diversity in the subtropical Chaco forest}

The majority of bee groups are highly diversified and abundant in warm temperate dry regions of the world (Michener 1979, 2007). However, they are poorly represented in moist tropical areas, where the major diversity 
and abundance of bees is due to the presence of highly eusocial Meliponini and Apini bees (Michener 1979, 2007; Roubik 1989; Alves dos Santos 1999), with 54 species of Meliponini collected near Manaus, Amazonas state, Brazil (Oliveira et al. 1995), 51 in the San Martín region of Peru (Rasmussen and Gonzalez 2009), 41 in Sao Paulo state of Brazil (Pedro and Camargo 1999) and more than 33 in the Meta region of Colombia (Nates-Parra 2005).

The Meliponini fauna decreases towards subtropical and temperate regions, with 13, 10 and 5 species found along a North-South latitudinal range from $23.5^{\circ} \mathrm{S}, 30^{\circ} \mathrm{S}$ to $31^{\circ} \mathrm{S}$, respectively, in southeastern Brazil (Alves dos Santos 1999). In the central part of the subtropical Chaco region, seven species were reported in the present work. However, some other species such as $P$. glabella Camargo and Moure, Melipona baeri Vachal, Melipona obscurior Moure, Schwarziana quadripunctata (Lepeletier), Trigona spinipes (Fabricius), Plebeia nigriceps (Friese) and other Plebeia species have been reported in neighbouring areas (Silvestri 1902; Schwarz 1932; Camargo and Moure 1988, 1994; Arenas 2003; Camargo and Pedro 2007a).

In a sector of central Argentina, only one species ( $P$. catamarcensis) was found, mainly associated with urban environments (Dalmazzo 2010). Meliponini richness decreases towards the south of the Chaco region, where forests become depauperate and climatic conditions are more severe. It is possible that the diminished richness of this mainly tropical bee lineage in subtropical and temperate regions is due to the fact that it has a restricted nest thermoregulation capability, as documented by Darchen (1973), Engels et al. (1995) and Cortopassi-Laurino and Nogueira-Neto (2003).

\subsubsection{Regional pattern of bionomics of the Chaquenian stingless bees}

Nesting adaptations of stingless bees to hot air and highly humid climate conditions of the tropics include the use of hydrophobic cerumen as a base material for building all nest parts (food pots, brood chamber, involucre, etc.) and for covering colonized hollow and entrance gallery walls of the nesting substrate (NogueiraNeto 1997; Roubik 2006), avoiding nest colonization and decomposition by fungi (Michener 2007). Thermoregulation is another adaptation found in Meliponini nests, which allows dispersion of excess heat in hot climates and heat conservation in cold climate conditions (Cortopassi-Laurino and Nogueira-Neto 2003), but it is poorly done by stingless bees that primarily rely on passive thermoregulation through nest site selection and nest architecture (Jones and Oldroyd 2007).

Tropical Meliponini bees display a broader diversity of feeding habits, nesting substrates, nest entrance architecture and building materials, and nest defence behaviour than their co-generic Chaquenian (subtropical) species (Table III).

In subtropical areas such as the Chaco region, periodic frost can occur and have a negative influence on flowering and bee flight activity. The subtropics are the meeting points for tropical and temperate faunas; thus, a rich bee fauna and consequently broad bionomical features are expected to be found, as denoted for several bee groups by Alves dos Santos (1999). However, due to the fact that nests of Meliponini bees show limited thermoregulation capacity, the severe climate conditions of the dry and transitional subtropical Chaco could account for the low richness of Meliponini species and the low diversity of bionomical features.

For the Meliponini fauna of the Chaco region, a regional pattern was elucidated. It includes (1) the absence of hemipterophily and necrophagy (feeding habits restricted to tropical species); (2) nests being located within wellprotected nesting substrates such as hard trunks, brick walls and soil, this leading to the absence of active ant-nest and termite-nest associations, as well as that of epiphyte root and exposed/ semi-exposed nests; (3) the absence of usage of faeces (coprophily), plant tissues and pure resin as building material of nest entrances; and (4) the absence of tremendously aggressive behaviour of bees (Table III). This pattern elements 
appear to be the reason for the broad diversity of bionomical features seen in the tropical Meliponini fauna (see Nogueira-Neto 1997; Roubik 1989, 2006; Camargo and Moure 1994, 1996; Rasmussen and Camargo 2008), but not so in the Chaquenian one.

\section{ACKNOWLEDGEMENTS}

I wish to thank Inocencio Medina, Isabel Brait, Rogelio Burgardt, Mercedes Koler, Ricardo "Nene" Vossler, Juan Hiperdinger and César Albornoz for their warm hospitality and help during the field studies. I thank Silvana Durante for starting the present study and Arturo Roig Alsina, Isabel Vilanova, Nora Brea and manuscript editor and reviewers for providing suggestions and comments on the manuscript. This study was supported by CONICET (Consejo Nacional de Investigaciones Científicas y Técnicas).

Fleurs visitées, comportement de nidification et de défense du nid chez les abeilles sans aiguillon (Apidae: Meliponini): choix des espèces appropriées à la méliponiculture dans la région argentine du Chaco.

Abeille agressive / tronc d'arbre mort / abeille docile / tronc d'arbre vivant / abeille subtropicale / Meliponini

Blütenbesuche, Nistverhalten und Nestverteidigung bei Stachellosen Bienen: Eignung verschiedener Arten für die Bienenhaltung in der ChacoRegion Argentiniens

Aggressive Biene / sanfte Biene / Totholzstämme / Lebendholzstämme / subtropische Stachellose Bienen

\section{REFERENCES}

Adámoli, J., Sennhauser, E., Acero, J.M., Rescia, A. (1990) Stress and disturbance: vegetation dynamics in the dry Chaco region of Argentina. J. Biogeogr. 17, 491-500

Alves dos Santos, I. (1999) Abelhas e plantas melíferas da Mata Atlântica, restinga e dunas do litoral norte do Estado do Rio Grande do Sul, Brasil. Rev. Brasil. Entomol. 41, 191-223
Antonini, Y., Costa, R.G., Martins, R.P. (2006) Floral preferences of a Neotropical stingless bee, Melipona quadrifasciata Lepeletier (Apidae: Meliponina) in an urban forest fragment. Braz. J. Biol. 66, 463-471

Arenas, P. (2003) Etnografía y alimentación entre los toba-ñachilamoleek y wichí lhuku'tas del Chaco Central (Argentina), Buenos Aires

Batista, M.A., Ramalho, M., Soares, A.E.E. (2003) Nesting sites and abundance of Meliponini (Hymenoptera: Apidae) in heterogeneous habitats of the Atlantic Rain Forest, Bahia, Brazil. Lundiana 4, 19 23

Brown, J.C., Albrecht, C. (2001) The effect of tropical deforestation on stingless bees of the genus Melipona (Insecta: Hymenoptera: Apidae: Meliponini) in central Rondonia, Brazil. J. Biogeogr. 28, 623-634

Cabrera, A.L. (1971) Fitogeografía de la República Argentina. Bol. Soc. Arg. Bot. 14, 1-42

Camargo, J.M.F. (1970) Ninhos e biologia de algumas espécies de Meliponídeos (Hymenoptera: Apidae) da região de Porto Velho, Território de Rondônia, Brasil. Rev. Biol. Trop. 16, 207-239

Camargo, J.M.F., Moure, J.S. (1988) Notas sobre os Meliponinae (Hymenoptera, Apidae) colecionados por Filippo Silvestri na Bacia do rio da Prata. Rev. Brasil. Entomol. 32, 293-314

Camargo, J.M.F., Moure, J.S. (1994) Meliponinae neotropicais: os gêneros Paratrigona Schwarz, 1938 e Aparatrigona Moure, 1951 (Hymenoptera, Apidae). Arq. Zool. 32, 33-109

Camargo, J.M.F., Moure, J.S. (1996) Meliponini neotropicais: o gênero Geotrigona Moure, 1943 (Apinae, Apidae, Hymenoptera) com especial referência à filogenia e biogeografía. Arq. Zool. 33, 95-161

Camargo, J.M.F., Pedro, S.R.M. (2002) Mutualistic association between a tiny Amazonian stingless bee and a wax-producing scale insect. Biotropica 34, 446-451

Camargo, J.M.F., Pedro, S.R.M. (2003) Meliponini neotropicais: o gênero Partamona Schwarz, 1939 (Hymenoptera, Apidae, Apinae) - bionomia e biogeografía. Rev. Brasil. Entomol. 47, 311-372

Camargo, J.M.F., Pedro, S.R.M. (2004) Meliponini neotropicais: o gênero Ptilotrigona Moure (Hymenoptera, Apidae, Apinae). Rev. Brasil. Entomol. 48, 353-377

Camargo, J.M.F., Pedro, S.R.M. (2007a) Meliponini Lepeletier, 1836. In: Moure, J.S., Urban, D., Melo, G.A.R. (eds.) Catalogue of bees (Hymenoptera, Apoidea) in the Neotropical region, pp. 272-578. Soc. Brasil. Entomol, Curitiba

Camargo, J.M.F., Pedro, S.R.M. (2007b) Notas sobre a bionomia de Trichotrigona extranea Camargo \& Moure (Hymenoptera, Apidae, Meliponini). Rev. Brasil. Entomol. 51, 72-81

Camargo, J.M.F., Roubik, D.W. (1991) Systematics and bionomics of the apoid obligate necrophages: the 
Trigona hypogea group (Hymenoptera: Apidae; Meliponinae). Biol. J. Linn. Soc. 44, 13-39

Carvalho, C.A.L., Marchini, L.C. (1999) Tipos polínicos coletados por Nannotrigona testaceicornis e Tetragonisca angustula (Hymenoptera, Apidae, Meliponinae). Sci. Agric. 56, 717-722

Carvalho, C.A.L., Marchini, L.C., Ros, P.B. (1999) Fontes de pólen utilizadas por Apis mellifera L. e algumas espécies de Trigonini (Apidae) em Piracicaba (SP). Bragantia 58, 49-56

Cortopassi-Laurino, M., Nogueira-Neto, P. (2003) Notas sobre a bionomia de Tetragonisca weyrauchi Schwarz, 1943 (Apidae, Meliponini). Acta Amaz. 33, 643-650

Cortopassi-Laurino, M., Imperatriz-Fonseca, V.L., Roubik, D.W., Dollin, A., Heard, T., Aguilar, I., Venturieri, G. C., Eardley, C., Nogueira-Neto, P. (2006) Global meliponiculture: challenges and opportunities. Apidologie 37, 275-292

Couvillon, M.J., Imperatriz-Fonseca, V.L., NogueiraNeto, P., Ratnieks, F.L.W. (2008) Comparative study in stingless bees (Meliponini) demonstrates that nest entrance size predicts traffic and defensivity. J. Evol. Biol. 21, 194-201

Dalmazzo, M. (2010) Diversidad y aspectos biológicos de abejas silvestres de un ambiente urbano y otro natural de la región central de Santa Fe, Argentina. Rev. Soc. Entomol. Arg. 69, 33-44

Darchen, R. (1973) La thermoregulation et l'ecologie de quelques espèces d'abeille sociales d'Afrique (Apidae, Trigonini et Apis mellifica var. adansonii). Apidologie 4, 341-370

Engels, W., Rosenkrans, P., Engels, E. (1995) Thermoregulation in the nest of the Neotropical stingless bee Scaptotrigona postica and a hypothesis on the evolution of temperature homeostasis in highly eusocial bees. Stud. Neotrop. Fauna \& Environm. 30, 193-205

Flores, F.F., Sánchez, A.C. (2010) Primeros resultados de la caracterización botánica de mieles producidas por Tetragonisca angustula (Apidae, Meliponinae) en Los Naranjos, Salta, Argentina. Bol. Soc. Arg. Bot. 45, 81-91

Imperatriz-Fonseca, V.L., Kleinert-Giovannini, A., Cortopassi-Laurino, M., Ramalho, M. (1984) Hábitos de coleta de Tetragonisca angustula angustula Latreille (Apidae, Meliponinae). Bol. Zool. Univ. São Paulo 8, 115-131

Jones, J.C., Oldroyd, B.P. (2007) Nest thermoregulation in social insects. Adv. Ins. Physiol. 33, 153-191

Kleinert-Giovannini, A., Imperatriz-Fonseca, V.L. (1987) Aspects of the trophic niche of Melipona marginata marginata Lepeletier (Apidae, Meliponinae). Apidologie 18, 69-100

Laroca, S., Sakakibara, A.M. (1976) Mutualismo entre Trigona hyalinata branneri (Apidae) e Aconophora flavipes (Membracidae). Rev. Brasil. Entomol. 20, $71-72$
Lima-Verde, L.W., Freitas, B.M. (2002) Occurrence and biogeographic aspects of Melipona quinquefasciata in NE Brazil (Hymenoptera, Apidae). Braz. J. Biol. 62, 479-486

Marques-Souza, A.C., Absy, M.L., Kerr, W.E. (2007) Pollen harvest features of the Central Amazonian bee Scaptotrigona fulvicutis Moure 1964 (Apidae: Meliponinae), in Brazil. Acta Bot. Bras. 21, 11-20

Martins, C.F., Cortopassi-Laurino, M., Koedam, D., Imperatriz-Fonseca, V.L. (2004) Espécies arbóreas utilizadas para nidificação por abelhas sem ferrão na Caatinga (Seridó, PB; João Camara, RN). Biota Neotropica 4, 1-8

Mendes dos Santos, G., Antonini, Y. (2008) The traditional knowledge on stingless bees (Apidae: Meliponina) used by the Enawene-Nawe tribe in western Brazil. J. Ethnobiol. Ethnomed. 4, 1-9

Michener, C.D. (1961) Observations on the nests and behavior of Trigona in Australia and New Guinea (Hymenoptera, Apidae). Am. Mus. Novit. 2026, 146

Michener, C.D. (1979) Biogeography of the bees. Ann. Mo. Bot. Gard. 66, 277-347

Michener, C.D. (1990) Classification of the Apidae (Hymenoptera). Univ. Kans. Scien. Bull. 54, 75164

Michener, C.D. (2007) The bees of the world, 2nd edn. The Johns Hopkins University Press, Baltimore

Moure, J.S. (2004) Duas espécies novas de Plebeia Schwarz do Brasil (Hymenoptera, Apidae, Meliponinae). Rev. Brasil. Entomol. 48, 199-202

Nates-Parra G. (2005) Biodiversidad y meliponicultura en el piedemonte llanero, Meta, Colombia, IV Seminario y Taller Mesoamericano sobre Abejas sin aguijón, El Salvador

Nogueira-Neto, P. (1997) Vida e criação de abelhas indígenas sem ferrão. Edição Nogueirapis, São Paulo. $445 \mathrm{pp}$

Nogueira-Neto, P., Sakagami, S.F. (1966) Nest structure of a subterranean stingless bee Geotrigona mombuca Smith (Meliponinae, Apidae, Hymenoptera). An. da Acad. Brasileira de Ciências 38, 187194

Noll, F.B. (1997) Foraging behavior on carcasses in the necrophagic bee Trigona hypogea (Hymenoptera: Apidae). J. lnsect Behav. 10, 463-467

Oliveira, M.L., Morato, E.F., Garcia, M.V.B. (1995) Diversidade de espécies e densidade de ninhos de abelhas sociais sem ferrão (Hymenoptera, Apidae, Meliponinae) em floresta de terra firme na Amazônia Central, Revta Bras. Zool. 12, 1324

Pedro, S.R.M., Camargo, J.M.F. (1999) Apoidea Apiformes. In: Joly, C.A., Bicudo, C.E.M. (eds.) Biodiversidade do Estado de São Paulo, Brasil, pp. 195-211. FAPESP, São Paulo 
Pennington, R.T., Prado, D.E., Pendry, C.A. (2000) Neotropical seasonally dry forests and Quaternary vegetation changes. J. Biogeogr. 27, 261273

Prado, D.E. (1993) What is the Gran Chaco vegetation in South America? I. A review. Contribution to the study of flora and vegetation of the Chaco. V. Candollea 48, 145-172

Ramalho, M. (1990) Foraging by stingless bees of the genus Scaptotrigona (Apidae, Meliponinae). J. Apic. Res. 29, 61-67

Ramalho, M. (2004) Stingless bees and mass flowering trees in the canopy of Atlantic Forest: a tight relationship. Acta Bot. Bras. 18, 37-47

Ramalho, M., Imperatriz-Fonseca, V.L., KleinertGiovannini, A., Cortopassi-Laurino, M. (1985) Exploitation of floral resources by Plebeia remota Holmberg (Apidae, Meliponinae). Apidologie 16, 307-330

Ramalho, M., Kleinert-Giovannini, A., ImperatrizFonseca, V.L. (1989) Utilization of floral resources by species of Melipona (Apidae, Meliponinae): floral preferences. Apidologie 20, 185-195

Ramalho, M., Kleinert-Giovannini, A., ImperatrizFonseca, V.L. (1990) Important bee plants for stingless bees (Melipona and Trigona) and Africanized honeybees (Apis mellifera) in Neotropical habitats: a review. Apidologie 21, 469-488

Ramalho, M., Silva, M.D., Carvalho, C.A.L. (2007) Dinâmica de uso de fontes de pólen por Melipona scutellaris Latreille (Hymenoptera: Apidae): uma análise comparativa com Apis mellifera L. (Hymenoptera: Apidae), no Domínio Tropical Atlântico. Neotrop. Entomol. 36, 38-45

Rasmussen, C., Camargo, J.M.F. (2008) A molecular phylogeny and the evolution of nest architecture and behavior in Trigona s.s. (Hymenoptera: Apidae: Meliponini). Apidologie 39, 1-10

Rasmussen, C., Gonzalez, V.H. (2009) Abejas sin aguijón del Cerro Escalera, San Martín, Perú (Hymenoptera: Apidae: Meliponini). Sist. Agroeco. Mod. Biomatemat. 2, 26-32

Robertson, C.H. (1925) Heterotropic bees. Ecology 6, $412-436$
Roubik, D.W. (1982) Obligate necrophagy in a social bee. Science 217, 1059-1060

Roubik, D.W. (1983) Nest and colony characteristics of stingless bees from Panamá (Hymenoptera: Apidae). J. Kans. Entomol. Soc. 56, 327-355

Roubik, D.W. (1989) Ecology and natural history of tropical bees. Cambridge University Press, New York

Roubik, D.W. (2006) Stingless bee nesting biology. Apidologie 37, 124-143

Sakagami, S.F., Laroca, S. (1953) Additional observations on the habits of the cleptobiotic stingless bees, the genus Lestrimelitta Friese (Hymenoptera, Apoidea). J. Fac. Sci. Hokkaido Univ. Ser. VI, Zool. 15, 319-339

Schwarz H.F. (1932) The genus Melipona. Bull. Am. Mus. Nat. Hist. 63, 231-460, pls. I-X

Schwarz, H.F. (1948) Stingless bees (Meliponidae) of the Western Hemisphere. Bull. Am. Mus. Nat. Hist. 90, $1-546$

Silvestri, F. (1902) Contribuzione alla conoscenza dei Meliponidi del Bacino del Rio de la Plata. Riv. Pat. Vegetale Portici 10, 121-174

Taura, H.M., Laroca, S. (1991) Abelhas altamente sociais (Apidae) de uma área restrita em Curitiba (Brasil): distribuição dos ninhos e abundancia relativa. Acta Biol. Par. 20, 85-101

Venturieri, G.C., Raiol, V.F.O., Pereira, C.A.B. (2003) Avaliação da introdução da criação recional de Melipona fasciculata (Apidae: Meliponina), entre os agricultores familiares de Bragança - PA, Brasil. Biota Neotrop. 3, 1-7

Vossler, F.G., Tellería, M.C., Cunningham, M. (2010) Floral resources foraged by Geotrigona argentina (Apidae, Meliponini) in the Argentine dry Chaco forest. Grana 49, 142-153

Wille, A. (1966) Notes on two species of ground nesting stingless bees (Trigona mirandula and T. buchwaldi) from the Pacific Rain Forest of Costa Rica. Rev. Biol. Trop. 14, 251-277

Wille, A., Michener, C.D. (1973) The nest architecture of stingless bees with special reference to those of Costa Rica (Hymenoptera, Apidae). Rev. Biol. Trop. 21, $1-128$ 